\title{
DEMOGRAFSKA ANALIZA OBMEJNEGA OBMOČJA SLOVENSKO - HRVAŠKE MEJE V SEVEROVZHODNI SLOVENIJI
}

\author{
Uroš Horvat*
}

Izvleček

UDK 911.3:312(497.12-18-04)

$V$ prispevku so analizirane nekatere demogeografske in socio - ekonomske razmere vobmejnem območju ob slovensko - hrvaški meji v Severovzhodni Sloveniji v obdobju 1961 - 1991.

Ključne besede: Meja, obmejno območje, demografska analiza, Slovenija

Abstract

UDC 911.3:312(497.12-18-04)

DEMOGRAPHIC ANALISIS OF THE SLOVENE - CROATIAN BORDER AREAS IN THE NORTN-EASTERN SLOVENIA

The article analyzes some demographic and socio-economic aspects in the Slovene-Croatian border areas in NE Slovenia between 1961 and 1991.

Key words: Border, border regions, demographic analisis, Slovenia

\section{UVOD}

Slovenijo lahko, zaradi njene teritorialne majhnosti in vpetosti $v$ mednarodne tokove, označimo skoraj v celoti kot obmejno regijo $\mathrm{z}$ vsemi učinki, ki so s tem povezani. Klemenčič (1992) ugotavlja v Sloveniji tri tipe obmejnih območij: območje ob meji z Italijo, Avstrijo in Madžarsko. Med seboj se razlikujejo tako po stopnji urbaniziranosti, propustnosti meje, regionalni povezanosti obmejnih območij sosednjih držav, času nastanka meje, fizično-geografski podobi, družbeno-ekonomski razvitosti, intenzivnosti pretoka oseb, blaga in informacij ter prekomejnem vplivanju človekovih aktivnosti na razvoj, vlogo in podobo kulturne pokrajine. Omenjenim tipom se je pridružil nov tip, to je obmejno območje ob meji s Hrvaško.

Z osamosvojitvijo Slovenije je leta 1991 nastala nova državna meja med R. Slovenijo in R. Hrvaško, ki je bistveno posegla $v$ gospodarske in blagovne tokove, zaposlovanje obmejnega prebivalstva, dnevno migracijo, urejanje prometa in podobno. Poleg nekaterih navedenih kratkoročnih učinkov pa se ob novonastali meji pričakujejo tudi dolgoročni učinki, ki so povezani predvsem $\mathrm{z}$ razvojem prebivalstva in gospodarstva $\mathrm{v}$ obmejnih območjih.

* Mag., asistent, Univerza v Mariboru, Pedagoška fakulteta, Oddelek za geografijo, Koroška cesta 160, 62000 Maribor, SLO 
$\mathrm{V}$ prispevku se omejujem le na predstavitev demogeografskih in nekaterih socio ekonomskih razmer, saj je prebivalstvo nosilec razvoja obmejne regije in s tem omogoča na eni strani ohranjanje poseljenosti in stabilnosti kulturne pokrajine, na drugi strani pa je tvoren element prekomejnega sodelovanja.

S pomočjo statističnega gradiva (t.j. rezultatov Popisa prebivalstva leta $1991 \mathrm{v}$ primerjavi s predhodnimi popisi) je analizirano stanje $\mathrm{v}$ demogeografskem razvoju $\mathrm{v}$ obmejnem območju ob slovensko - hrvaški meji v SV Sloveniji pred nastankom nove meje. Rezultati nam bodo služili kot osnova za nadaljnjo proučevanje in ugotavljanje možnih učinkov ob novonastali državni meji.

V analizo so bili vključeni naslednji kazalci:

- gibanje števila prebivalstva v obdobju 1869 - 1991

- gibanje števila gospodinjstev v obdobju 1961 - 1991

- starostna in spolna struktura prebivalstva leta 1961 in 1991

- delež kmečkega prebivalstva leta 1961 in 1991

- delež priseljenega prebivalstva z območja bivše Jugoslavije leta 1991.

Obravnavano obmejno območje zajema pet občin (Lendava, Ljutomer, Ormož, Ptuj in Šmarje pri Jelšah). Analiza je izdelana na nivoju katastrskih občin, ki so bile razvrščene v štiri pasove (karta 1):

-k.o. tik ob meji

- k.o., ki so od meje oddaljene največ $5 \mathrm{~km}$, a niso neposredno povezane $\mathrm{z}$ mejo

- k.o., ki so od meje oddaljene $5-10 \mathrm{~km}$

- ostale k.o. v obmejnih občinah.

Med 403 katastrskimi občinami jih v prvi pas sodi 71 , v drugi pas 99 , v tretji 119 in v četrti 114. V tabelah so prikazani rezultati analize po naravno - geografskih regijah, saj so edhodni rezultati pokazali večjo povezanost demogeografskih razmer s temi enotami kot $\mathrm{z}$ upravnimi občinami. Na kartah pa so za primerjavo prikazane tudi razmere $\mathrm{v}$ občini Murska Sobota. Tu je odprta meja $\mathrm{z}$ Avstrijo pripomogla $\mathrm{k}$ gospodarskemu in družbenemu razvoju na Zahodnem Goričkem, medtem ko je na drugi strani (na V Goričkem) ob štirideset let zaprti meji prišlo do izrazite depopulacije in propada kulturne pokrajine (Klemenčič, 1991; Počkaj-Horvat, 1991; Horvat, 1993).

\section{GIBANJE ŠTEVILA PREBIVALSTVA V OBDOBJU 1869 - 1991}

Obravnavano območje sodi med manj razvita območja Slovenije že od prvega Zakona o ukrepih za pospeševanje razvoja manj razvitih območij (Piry, 1992). V večini območja se namreč število prebivalcev v povojnem obdobju konstantno zmanjšuje. Medtem ko se je v Sloveniji v obdobju 1961 - 1991 število prebivalstva povečalo za $24,6 \%$, se je v obravnavanih petih občinah povečalo le za $2,2 \%$ in še to le na račun povečanja v občinskih 
Slika 1: Obmejno območje ob slovensko-hrvaški meji v SV Sloveniji Slovene-Croatian Border Areas in North-Eastern Slovenia

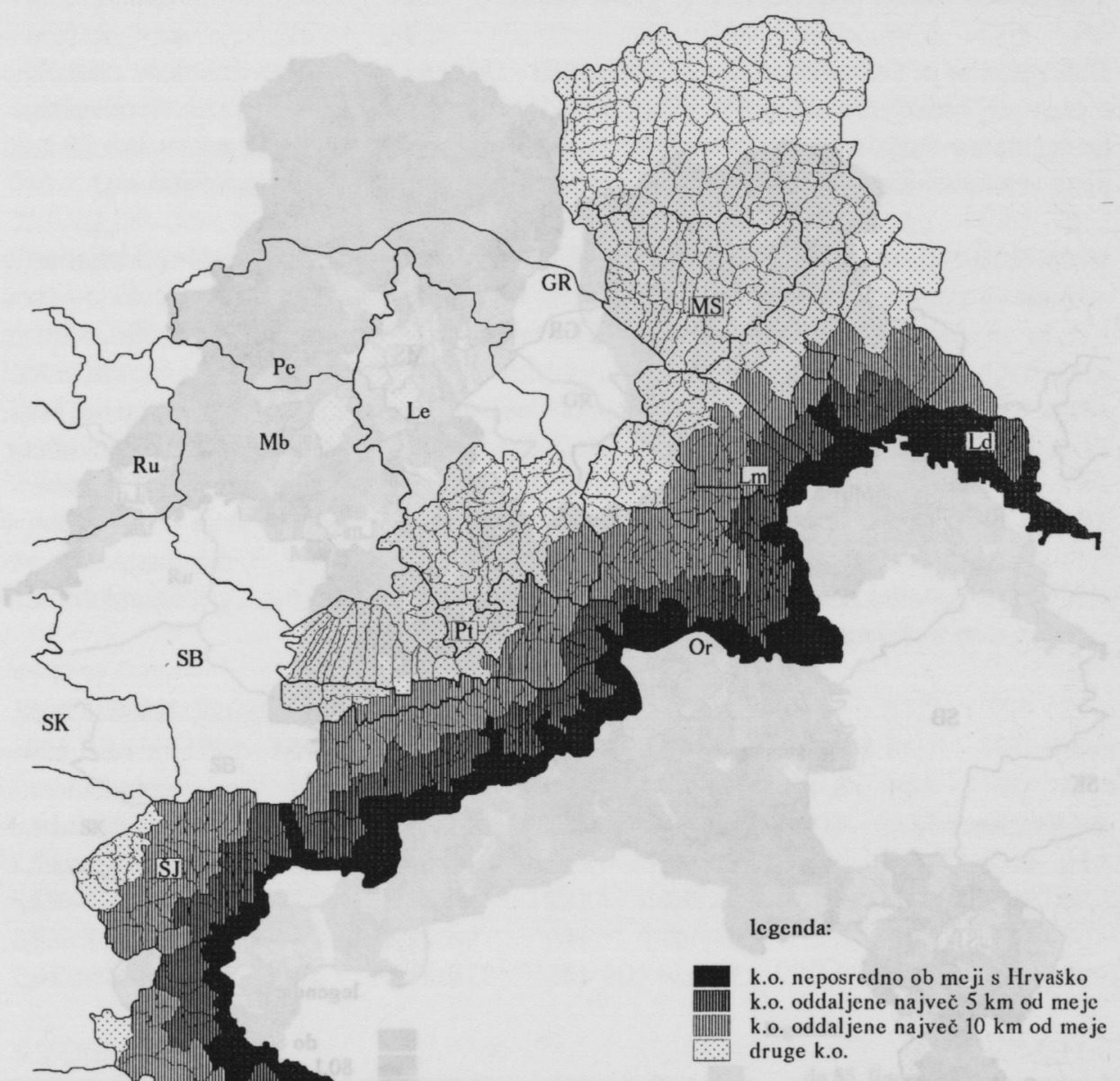


Slika 2: Gibanje števila prebivalstva v obdobju 1961-81 v občinah SV Slovenije ob meji s Hrvaško

Changes in the Number of Population from 1961-81 in the Slovene-Croatian Border Communes in NE Slovenia

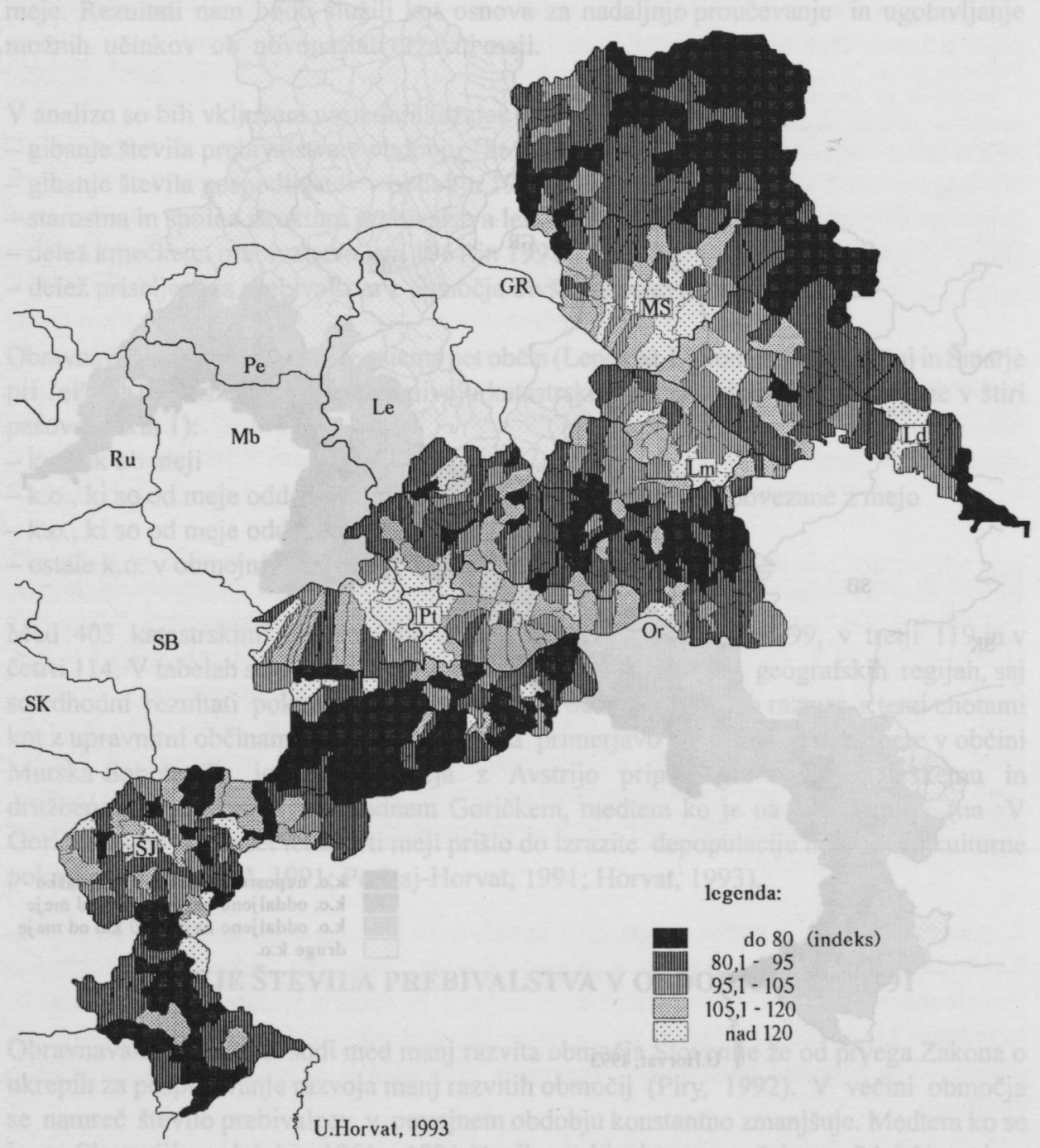


Demografska analiza obmejnega...

Slika 3: Gibanje števila prebivalstva v obdobju 1981-91 v občinah SV Slovenije ob meji s Hrvaško

Changes in the Number of Population from 1981-91 in the Slovene-Croatian Border Communes in NE Slovenia

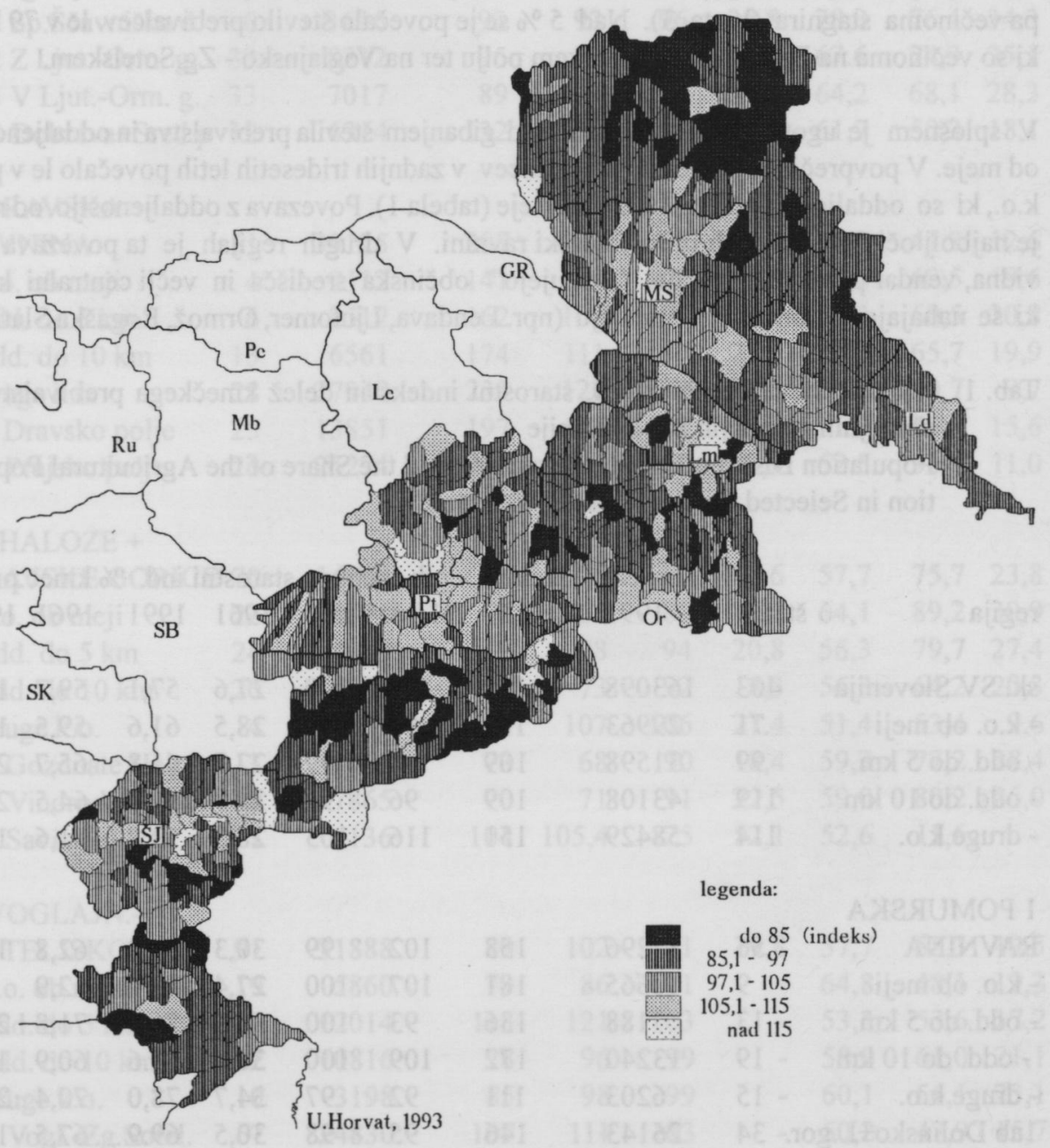


Demografska analiza obmejnega...

središčih in večjih centralnih krajih (karta 2). Leta 1991 je v regiji živelo 163.098 prebivalcev.

Depopulacija je najmočnejša v Halozah (v obdobju 1961 - 1991 se je število prebivalcev zmanjšalo za $30 \%$ ), v Vzhodnih Ljutomersko - Ormoških goricah (za $21 \%$ ) in na Kozjanskem (za $20 \%$ ). V omenjenih regijah je bilo leta 1991 celo manj prebivalcev kot leta 1869 (tabela 1). To je posledica tako neugodnega naravnega gibanja kot intenzivnih migracijskih tokov v preteklosti (Ogrinc, 1983).

Depopulacija je intenzivna tudi v obdobju 1981 - 1991, saj se število prebivalcev zmanjšuje v vseh prej omenjenih regijah; $v$ tistih, ki so $v$ preteklem obdobju izkazovali povečanje, pa večinoma stagnira (karta 3 ). Nad $5 \%$ se je povečalo število prebivalcev le v 79 k.o., ki so večinoma na Dravskem in Murskem polju ter na Voglajnsko - Zg.Sotelskem.

$\mathrm{V}$ splošnem je ugotovljena povezava med gibanjem števila prebivalstva in oddaljenostjo od meje. $V$ povprečju se je število prebivalcev $v$ zadnjih tridesetih letih povečalo le $v$ pasu k.o., ki so oddaljene več kot $10 \mathrm{~km}$ od meje (tabela 1). Povezava z oddaljenostjo od meje je najbolj očitna v Halozah in na Dravski ravnini. V drugih regijah je ta povezava tudi vidna, vendar povprečje regije "dvigujejo" občinska središča in večji centralni kraji, ki se nahajajo v obmejnem območju (npr. Lendava, Ljutomer, Ormož, Rogaška Slatina).

Tab. 1: Gibanje števila prebivalcev, starostni indeks in delež kmečkega prebivalstva v obmejnih območjih SV Slovenije

Population Distribution, Age Structure and the Share of the Agricultural Population in Selected Border Areas of Slovenie

regija

sk. SV Slovenija

- k.o. ob meji

- odd. do $5 \mathrm{~km}$

- odd. do $10 \mathrm{~km}$

- druge k.o.

\section{POMURSKA}

\section{RAVNINA}

- k.o. ob meji

- odd. do $5 \mathrm{~km}$

- odd. do $10 \mathrm{~km}$

- druge k.o.

št.KO

št.preb.

indeks

gib.prebiv. starostni ind. \% kmeč.preb.

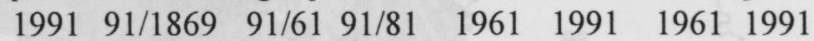

$\begin{array}{rrrrrrrrr}403 & 163098 & 122 & 102 & 100 & 27,6 & 57,1 & 59,7 & 19,2 \\ 71 & 29963 & 112 & 94 & 99 & 28,5 & 61,6 & 59,5 & 17,2 \\ 99 & 31598 & 109 & 98 & 99 & 27,7 & 61,8 & 65,7 & 22,3 \\ 119 & 43108 & 109 & 96 & 97 & 259 & 57,3 & 64,5 & 22,3 \\ 114 & 58429 & 151 & 116 & 103 & 28,3 & 52,2 & 51,6 & 16,2\end{array}$

1ab Dolinsko+L.gor. 34

1c Mursko polje 22
37296

10665

7188

13240

6203

26143

11153

\section{3}

181

136

172

111

146

172
102

107

93

109

92

95

122
99

100

100

100

97

98

103

\section{0,3}

27,4

30,5

30,2

34,7

30,5

$29,6 \quad 56,4$
$62,8 \quad 18,2$

$52,9 \quad 9,2$

$\begin{array}{ll}71,8 & 22,9\end{array}$

$\begin{array}{ll}60,9 & 19,6\end{array}$

$\begin{array}{ll}70,4 & 25,3\end{array}$

$\begin{array}{ll}67,5 & 18,9\end{array}$

$\begin{array}{lll}48,4 & 16,7\end{array}$ 
Demografska analiza obmejnega...

2a OSR.SLOVENSKE

$\begin{array}{lrrrrrrrrr}\text { GORICE } & 51 & 17532 & 128 & 120 & 116 & 27,6 & 39,1 & 68,2 & 19,2 \\ \text { - odd. do } 10 \mathrm{~km} & 7 & 1633 & 100 & 89 & 99 & 25,8 & 43,2 & 79.3 & 29,4 \\ \text { - druge k.o. } & 44 & 15899 & 131 & 124 & 118 & 27,9 & 38,7 & 66,7 & 18,2\end{array}$

2b VZH.SLOVENSKE

$\begin{array}{lrrrrrrrrr}\text { GORICE } & 84 & 23159 & 101 & 88 & 97 & 28,9 & 65,7 & 67,1 & 28,3 \\ \text { - k.o. ob meji } & 17 & 7435 & 129 & 103 & 101 & 32.4 & 59,6 & 54,1 & 18,9 \\ \text { - odd. do } 5 \mathrm{~km} & 26 & 5825 & 91 & 83 & 96 & 26,3 & 64,7 & 67,5 & 29,6 \\ \text { - odd. do 10 km } & 28 & 6599 & 94 & 82 & 94 & 27,1 & 67,6 & 72,0 & 31,4 \\ \text { - druge k.o. } & 13 & 3300 & 86 & 83 & 94 & 32,1 & 77,8 & 82,0 & 41,0 \\ \text { 2b1 Sp.Ščavniška d. } & 6 & 1616 & 93 & 93 & 96 & 30,8 & 78,0 & 76,4 & 34,3 \\ \text { 2b2 Z Ljut.-Orm. g. } & 33 & 8212 & 95 & 83 & 94 & 29,4 & 67.6 & 74,3 & 35,1 \\ \text { 2b3 V Ljut.-Orm. g. } & 33 & 7017 & 89 & 79 & 94 & 24,3 & 64,2 & 68,1 & 28,3 \\ \text { 2b4 Dobrava+Sred.p } & 12 & 6314 & 132 & 110 & 103 & 36,0 & 61,7 & 50,3 & 18,1\end{array}$

\section{DRAVSKA}

\section{RAVNINA}

- k.o. ob meji

- odd. do $5 \mathrm{~km}$

- odd. do $10 \mathrm{~km}$

- druge k.o.

3a Dravsko polje 25

3b Ptujsko polje 26

\section{1}

4

6

13

28

26
39125

2112

2512

6561

27940

13851

25274

\section{7}

141

162

174

231

197

213

\section{2}

109

106

111

128

113

127
99

102

97

97

99

102

98
$27,2 \quad 52,2$

$36,0 \quad 52,6$

$39,9 \quad 68,3$

$\begin{array}{ll}23,9 & 47,7\end{array}$

$26,0 \quad 51,7$

$24,0 \quad 51.5$

20,3
$41.3 \quad 12,6$

$\begin{array}{ll}62,5 & 19,6\end{array}$

$\begin{array}{ll}60,5 & 20,8\end{array}$

$\begin{array}{ll}65,7 & 19,9\end{array}$

$\begin{array}{ll}30,7 & 9,7\end{array}$

$45,4 \quad 15,6$

$38,7 \quad 11,0$

45 HALOZE +

DRAVSKE GORICE 70

- k.o. ob meji

- odd. do $5 \mathrm{~km}$

- odd. do $10 \mathrm{~km}$

- druge k.o.

4a Gozdnate Haloze 13

4 b Vinorod. Haloze 49

5a Savinsko

2771
14098

3891

4059

4259

1889

3462

7865

136
78

$64 \quad 65$

$77 \quad 78$

$79 \quad 73$

$145 \quad 107$

$\begin{array}{ll}73 & 68\end{array}$

$70 \quad 71$

$104 \quad 105,4$

$$
93
$$

89

94

92

106

90

91

25
21.6

$24,2 \quad 64,1$

$20,8 \quad 56,3$

$\begin{array}{ll}18,3 & 56,3\end{array}$

$27.4 \quad 51,4$

$18,4 \quad 59,3$

$22,5 \quad 59,0$

52 ,
6 VOGLAJN.-

\section{SOTELJSKO}

- k.o. ob meji

- odd. do $5 \mathrm{~km}$

- odd. do $10 \mathrm{~km}$

- druge k.o.

31888

$30 \quad 12014$

32

10

6a Vogl.-Zg.Sotel. 67

6b Kozjansko
$89 \quad 102$

$\begin{array}{lll}79 & 86 & 101\end{array}$

$\begin{array}{lll}113 & 121 & 103\end{array}$

$\begin{array}{lll}78 & 96 & 99\end{array}$

$\begin{array}{lll}85 & 98 & 99\end{array}$

$\begin{array}{lll}107 & 111 \quad 103\end{array}$

$\begin{array}{lll}56 & 80 & 92\end{array}$ $\begin{array}{ll}75,7 & 23,8\end{array}$

$89,2 \quad 30,9$

$\begin{array}{ll}79,7 & 27,4\end{array}$

$64,2 \quad 20,3$

$53,4 \quad 9,6$

$\begin{array}{ll}77,2 & 28,4\end{array}$

$80,2 \quad 26,0$

11,6 
Slika 4: Gibanje števila gospodinjstev v obdobju 1961 - 1991 v občinah SV Slovenije ob meji s Hrvaško

Changes in the Number of Hauscholds from 1961 to 1991 in the Slovene-Croatian Border Communes in NE Slovenia

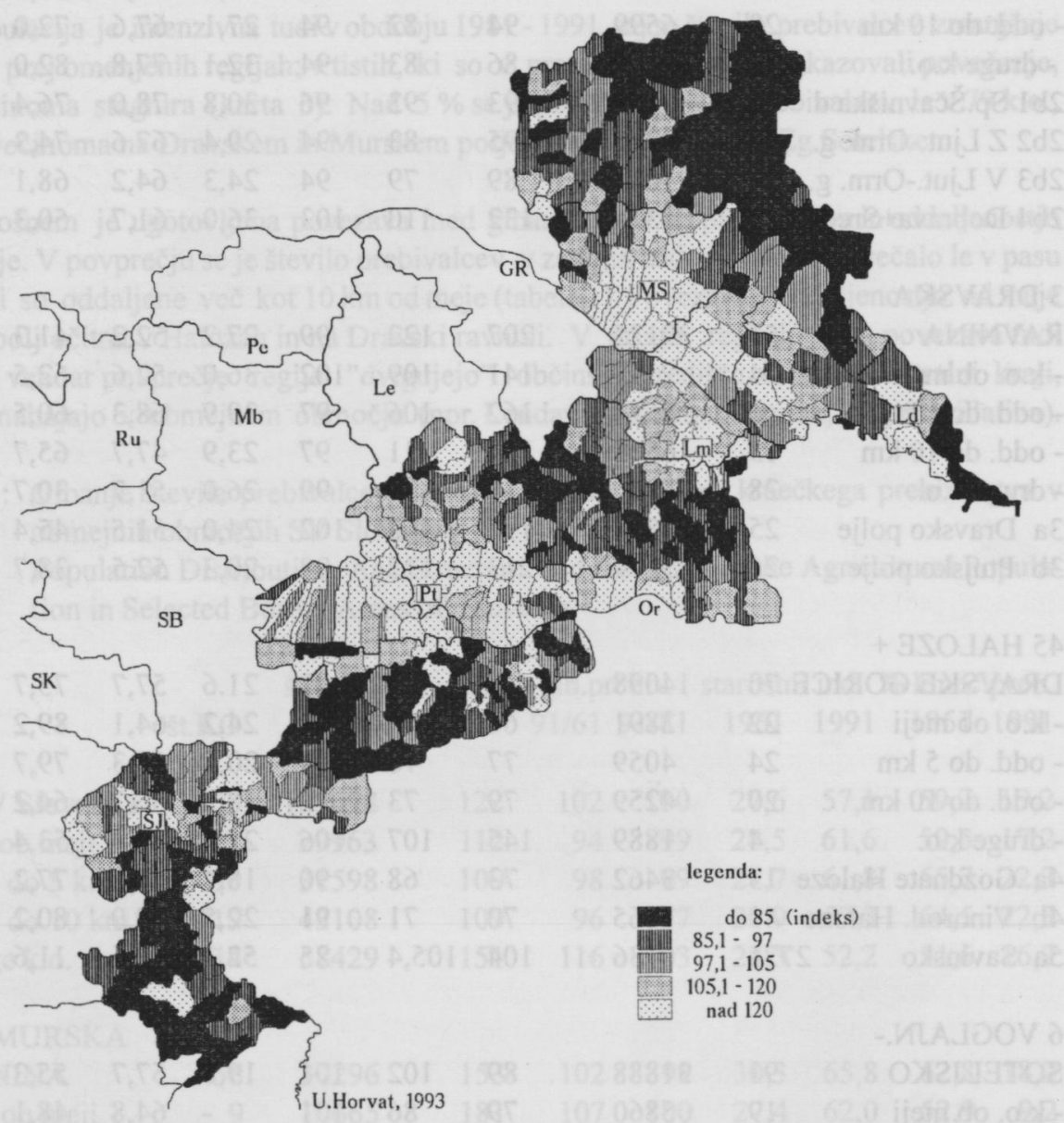


Za državnim povprečjem zaostaja tudi gibanje števila gospodinjstev. Zaradi spremenjenega načina življenja, oziroma prehoda iz agrarne $\mathrm{v}$ urbano družbo, se je $\mathrm{v}$ Sloveniji v obdobju 1961 - 1991 število gospodinjstev povečalo za $40 \%$, v obmejnih območjih SV Slovenije pa le za $19 \%$. Tu je prehod opazen šele v zadnjih desetih letih, ko v vseh regijah število gospodinjstev rahlo narašča, medtem ko se je v obdobju 1961 - 1981 zlasti v Vzhodnih Slovenskih goricah, Halozah in na Kozjanskem intenzivno zmanjševalo. $\mathrm{V}$ omenjenih regijah se je $\mathrm{v}$ obdobju 1961 - 1991 število gospodinjstev zmanjšalo kar v 143 k.o. (od 229 k.o.).

Povprečno število članov na gospodinjstvo je v obmejnem območju SV Slovenije višje kot v Sloveniji in znaša 3,35 prebivalca na gospodinjstvo leta 1991 (v Sloveniji 3,08).

\section{STAROSTNA IN SPOLNA STRUKTURA PREBIVALSTVA LETA 1961 IN 1991}

Starostna struktura prebivalstva je odraz splošne dinamike prebivalstva in družbeno geografskih razmer v regiji. Delež mladega prebivalstva (do 14 let), ki je leta $1961 \mathrm{v}$ agrarno prenaseljenih območjih SV Slovenije znašal 30,0 \%, se je leta 1991 znižal na 20,5\%; delež starega prebivalstva (nad 65 let) pa se je zvišal z 8,3\% na $11,7 \%$. Najvišji je na Kozjanskem (nad $17 \%$ ) ter v Vzhodnih Slovenskih goricah in na Dolinskem (nad $14 \%)$.

To je vplivalo tudi na neugodno razmerje med obema starostnima skupinama, ki ga izraža starostni indeks. Medtem ko je imelo obravnavano območje leta 1961 ugodnejši starostni indeks kot Slovenija, je bil ta leta 1991 v regiji $(57,1)$ višji kot v državi $(53,1)$. Kar v 56 k.o. je bilo starejšega prebivalstva več kot mladega (karta 5). Delež moškega prebivalstva se je zvišal z povprečja $47 \%$ leta 1961 na $49 \%$ leta 1991.

\section{DELEŽ KMEČKEGA PREBIVALSTVA LETA 1961 IN 1991}

Čeprav je bil razkroj agrarne strukture prebivalstva v obravnavanem območju dokaj intenziven, kar se kaže tako v intenzivnem mehaničnem gibanju prebivalstva in staranju le-tega, je še vedno dobršen del prebivalstva povezan s kmetijsko proizvodnjo. Tako se je delež kmečkega prebivalstva iz leta 1961 (59,7 \% v celotnem območju; v Halozah npr. preko 80 \%) znižal v letu 1991 na 19,2 \%, kar pa je še vedno 2,4 - krat več kot znaša povprečje Slovenije.

Zaposlovanje slabše izobraženega in nižje kvalificiranega prebivalstva $\mathrm{v}$ bližnjih zaposlitvenih centrih je vzpostavilo polkmečko strukturo, kjer je mlajše prebivalstvo večinoma zaposleno, starejše pa dela na kmetiji. V Halozah, Vzhodnih Slovenskih goricah in na Kozjanskem je še vedno 25 - 35 \% vsega prebivalstva kmečkega (tabela 2, karta 6). Več kot $50 \%$ kmečkega prebivalstva je še vedno v 12 k.o. obravnavanega območja. 
Slika 5: Delež prebivalstva, priseljenih iz republik bivše Jugoslavije, stanje leta 1991 Proportion of the Population that Immigrated from Former Yugoslav Republics Data for the Year 1991.

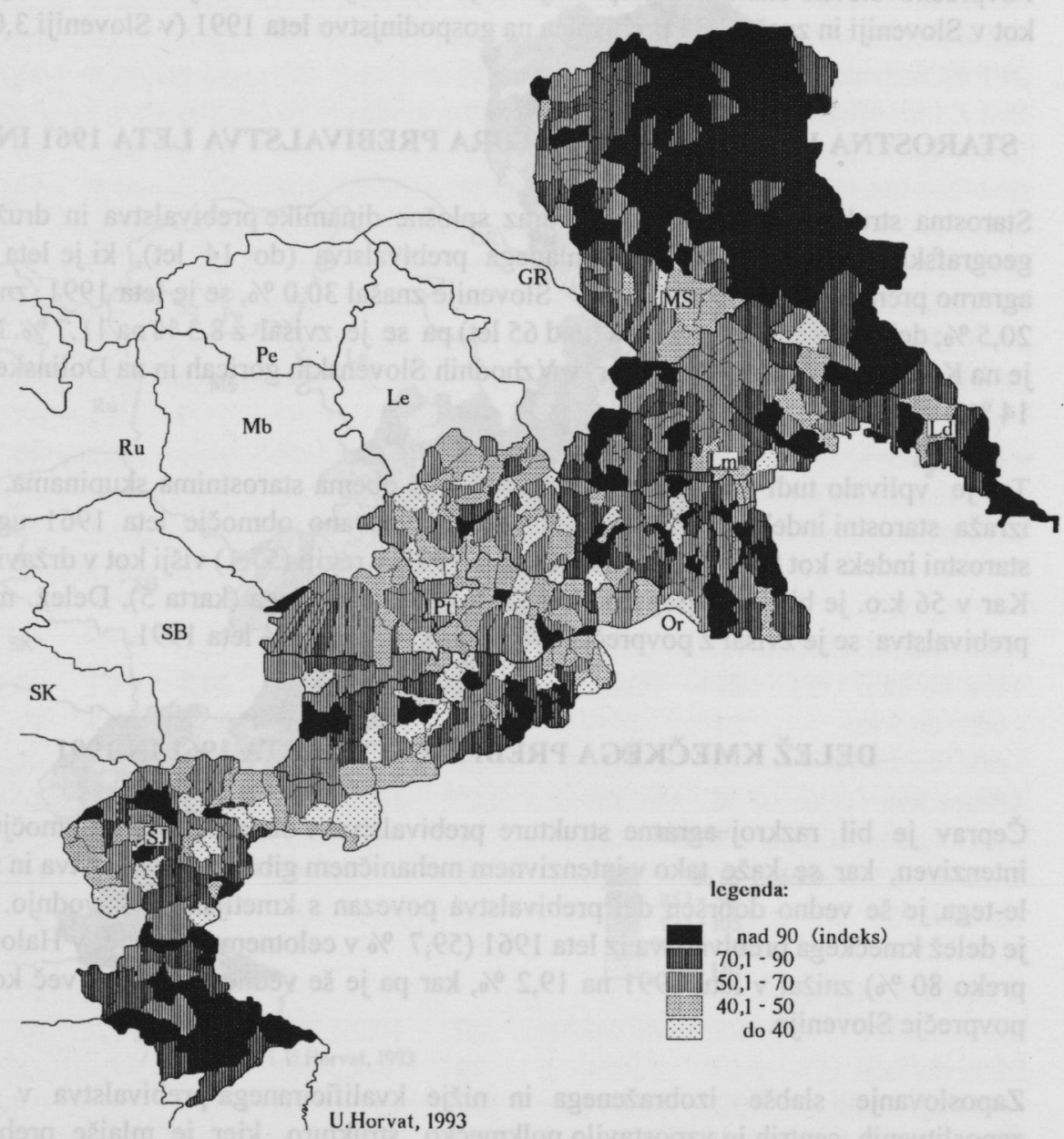


Deagrarizacija je bila intenzivna le na ravninskem območju, kjer sta se pričeli urbanizacija in industrializacija relativno zgodaj. Tu prevladujejo goispodinjstva s kmečkim gospodarstvom $v$ katerih so vsi odrasli zaposleni izven kmetijstva, delo na zemlji pa jim služi kot dodatni vir dohodka.

\section{DELEŽ PRISELJENEGA PREBIVALSTVA Z OBMOČJA BIVŠE JUGOSLAVIJE}

Za proučevanje dogajanj $\mathrm{v}$ obmejnem območju je pomembna tudi analiza priseljenega prebivalstva. $\mathrm{V}$ preteklosti so se iz republik bivše Jugoslavije zlasti v večje zaposlitvene centre priseljevali delovni migranti. V nekaterih občinah osrednje Slovenije in na Primorskem znaša njihov delež preko $15 \%$ vsega prebivalstva. Zaradi manjše razvitosti je $v$ obravnavanih obmejnih občinah ta delež sorazmeroma nizek $(2,6-4,1 \%$ vsega prebivalstva).

Kot posledica trajnih preseljevanj zaradi dela in mešanja prebivalstva s porokami so višji deleži priseljenega prebivalstva le v k.o., ki so neposredno ob meji. Kar v 21 k.o. ob sami meji znaša delež priseljenih iz bivše Jugoslavije nad $10 \%$ vsega prebivalstva. To so večinoma Hrvati iz sosednjih območij preko meje. Najvišji so deleži priseljenega prebivalstva v Lendavi (13\%), Petišovcih (14\%), Globoki (14,2 \%), Razkrižju (15,6 \%), Šafarskem (14,6\%), Gibini (14\%), Središču ob Dravi (14,3\%), Zavrču (30 \%), Drenovcu (28 \%), Rogatcu (26,9\%), Vonarjah (16,2) in v Rogaški Slatini (15\%) (karta 7).

\section{ZAKLJUČEK}

Meja med R. Slovenijo in R. Hrvaško je bila v preteklosti le administrativna ločnica in je bila popolnoma odprta. Demografski razvoj proučevanega obmejnega območja je tako rezultat pokrajinskih razmer (zlasti reliefa) in celotnega družbeno - ekonomskega razvoja. Policentrični razvoj Slovenije in industrializacija večjih centralnih krajev sta sprožila deagrarizacijo in depopulacijo slovenskega podeželja. Na območju SV Slovenije so bili ti procesi intenzivni zlasti v terciarnem gričevju (Goričko, Slovenske gorice, Haloze, Kozjansko, idr.). Problematika manjše razvitosti v Sloveniji je dobro poznana in obdelana v strokovni literaturi, kar je imelo za posledico tudi to, da se je večina analiziranega območja uvrstila med nerazvita že po prvem zakonu o manj razvitih območjih v Sloveniji leta 1971.

Analiza je pokazala, da so v zadnjih tridesetih letih ravninska območja doživela intenziven razvoj, periferna, še zlasti obmejna območja pa so zaostala. Infrastruktura in druge družbeno - ekonomske dejavnosti so zaradi perifernosti $\mathrm{z}$ obeh strani slabo razvite tako $\mathrm{v}$ Sloveniji kot tudi na Hrvaškem. Žal nam o stopnji razvitosti na hrvaški strani manjkajo podatki. 
Zaradi tega je potrebno na novo koncipirati regionalni razvoj obmejnih območij in pospešiti izgradnjo infrastrukture in drugih dejavnosti, ki bodo zadržale poselitev in stem ohranjanje kulturne pokrajine. V razvoj je potrebno vključiti lokalno prebivalstvo kot pomemben razvojni dejavnik.

\title{
DEMOGRAPHIC ANALYSIS OF THE SLOVENE-CROATIAN BORDER AREAS IN NORTH-EASTERN SLOVENIA
}

\author{
Summary
}

The independence of Slovenia, gained in 1991, had for its consequence a new state border between the Republic of Slovenia and the Republic of Croatia. The new border has had a considerable impact on the economy and commerce, employment of the local population, daily migration, traffic regulation and the like. In addition to the mentioned short-term effects, more long-term ones that have to do with demographic development and economy in borderline areas are expected.

Statistical data (comparison of the results from the 1991 Census and previous ones) were used to analyze the state of demographic development in the borderline areas along the Slovene-Croatian border in NE Slovenia in the period prior to the creation of the new border. The results will serve as a basis for futher research and determination of possible effects of the border.

The following indicators were included in the study.

- changes in the number of population between 1869-1991

- changes in the number of households between 1961-1991

- age and sex structure of population in the years 1961 and 1991

- the proportion of rural population in the years 1961 and 1991

- the proportion of immigrants from the territories of former Yugoslavia in 1991

The mentioned borderline area consists of five communes (Lendava, Ljutomer, Ormož, Ptuj and [marje pri Jelšah). The analysis was carried out on the level of cadastral communes, which were classified into four belts:

- cadastral communes located immediately along the border

- cadastral communes that are located maximally 5 kilometers from the border, but are not directly linked to it

- cadastral communes that are located 5-10 kilometers from the border

- the remaining cadastral communes in borderline communes

In the past, the border between the two states was only an administrative division and 
was completely open. The demographic development of the region under investigation is therefore the result of landscape conditions (especially the relief) and of the general socio-economic development. The polycentric development in Slovenia and the industrialization of larger centers resulted in deagrarization.

The analysis shows that, in the past thirty years, flat regions have undergone an intensive development, while peripheral and especially borderline regions lagged behind in development. It is bacause of their socio-economic activities have remained underdeveloped both in Slovenia and in Croatia.

It is therefore necessary to create a new concept of regional development in borderline areas, which will accelerate the construction of infrastructure and other activities, this stoping emigration and preserving a cultivated landscape. Local population, who is actively involved in across-the-border cooperation, has to be included in this development. 